\title{
Investigation of the Hydrological Quality of Ethiope River Watershed, Southern Nigeria
}

\section{OMO-IRABOR, O O; *OLOBANIYI, S B}

\author{
Department of Geology, Delta State University, P.M.B. 1, Abraka, Delta State, Nigeria Email: sbolobaniyi@yahoo.com Ph +234-802- \\ 3529637
}

\begin{abstract}
The surface and groundwater resources of the Ethiope river watershed have been investigated for its hydrological and quality characteristics. The results indicate that Ethiope River is perennial and fed by groundwater seepages, precipitation and surface run-off from adjacent areas. The lowest discharge rate of the river is recorded in June and increases steadily reaching its peak in October. The physico-chemical parameters of both water sources include, $\mathrm{pH}(5.28-7.06)$, turbidity $(1.16-8.12 \mathrm{NTU})$, conductivity $(65.00-127.0 \mu \mathrm{s} / \mathrm{cm})$, dissolved oxygen $(4.40-7.60$ $\mathrm{mg} / \mathrm{l})$ and total hardness $(25.50-45.0 \mathrm{mg} / \mathrm{l})$. Others include, $\mathrm{Na}^{+}(3.91-27.05 \mathrm{mg} / \mathrm{l}), \mathrm{K}^{+}(3.91-8.73 \mathrm{mg} / \mathrm{l}), \mathrm{Ca}^{2+}$ (3.21 - $9.60 \mathrm{mg} / \mathrm{l}), \mathrm{Mg}^{2+}(1.46-5.84 \mathrm{mg} / \mathrm{l}), \mathrm{HCO}_{3}{ }^{-}(31.50-80.00 \mathrm{mg} / \mathrm{l}), \mathrm{Cl}^{-}(17.55-35.10 \mathrm{mg} / \mathrm{l}), \mathrm{SO}_{4}{ }^{2-}(0.25-0.58$ $\mathrm{mg} / \mathrm{l}), \mathrm{NO}_{3}{ }^{2-}(0.19-0.55 \mathrm{mg} / \mathrm{l})$ and $\mathrm{PO}_{4}{ }^{2-}(0.20-19.00 \mathrm{mg} / \mathrm{l})$. This physico-chemical quality is generally compatible with WHO guideline for domestic use. Nevertheless, the water samples consist of high microbial population including total coliform bacteria counts $(39.00-1100 \mathrm{MPN} / 100 \mathrm{ml})$ and Escherichia coli $(21.00$ - 305.00 MPN/100ml), which render both surface and groundwater unfit for domestic use without disinfection. An assessment of surface water-groundwater homogeneity using the parametric student's $t$ and $F$ tests on selected constituents (chloride, nitrate, sulphate, phosphate, sodium, potassium, calcium and magnesium), indicate non-significance in the variation within the tested parameters except for nitrate. This suggests some groundwater-surface water intermixing or communication, and the activity of denitrifying bacteria in surface water. A groundwater pollution vulnerability assessment using DRASTIC model indicates moderately high pollution risk level for the aquifer system. @JASEM
\end{abstract}

The quantity as well as quality of water available for the replenishment of surface water bodies and groundwater recharge is of paramount importance to the sustenance of life. In tropical environments, rainfall is the main source of such replenishment. Rainfall reaching the surface of the earth is separated into two flow components: the horizontal (storm runoff) and vertical infiltration. Infiltration and subsequent percolation of vertical flow component serves as source of recharge for the aquiferous layers in the area. Generally, the quality of water passing through the hydrologic cycle is affected by such factors as soil, vegetation, geomorphology, geology and anthropogenic activities. The influence of these factors either improves or degrades water quality. Therefore, evaluating the chemical and bacteriological constituents of surface water and groundwater is essential in appraising their quality and suitability for various purposes.

The River Ethiope (Figure 1) takes its source from a spring at Umuaja and flows for over $100 \mathrm{~km}$ to empty into river Benin. This river serves as the terminal point for storm runoff in the study area. The inhabitants of surrounding villages rely mainly on the river for their domestic water supply, fishing, sandmining and inter-village transportation. At the lower reaches of the river, it is subject to the tidal influence of the Atlantic Ocean.

To a lesser extent, groundwater is also tapped from dug and tube wells for domestic, industrial and agricultural activities. Previous studies within the watershed centered primarily on the hydrobiology (Ikomi, 1992; 1996) and economic potential
(Adiotomre el al, 1999) of the Ethiope River. This study attempts to assess the hydrological characteristics of the Ethiope River watershed, and appraises the vulnerability of its sub-surface aquifer to contamination by pollutants. It also highlights the potability of water resources within the watershed.

Geographical Setting: The study area is situated in the north central part of Delta State between latitudes $5^{\circ} 40^{\prime} 6^{\prime \prime} \mathrm{N}$ and $6^{\circ} 00^{\prime} \mathrm{N}$ and longitudes $5^{\circ} 39^{\prime} 5^{\prime \prime} \mathrm{E}$ and $6^{\circ} 10^{\prime} 9 " \mathrm{E}$ (Figure 1). It is located within the equatorial region having two climatic regimes: the wet season, which begins in April and lasts till October and the dry season from November to March. The average annual rainfall is about $2800 \mathrm{~mm}$ with temperatures varying between $23^{\circ} \mathrm{C}$ and $37^{\circ} \mathrm{C}$ in the afternoon and dropping to between $18^{\circ} \mathrm{C}$ and $22^{\circ} \mathrm{C}$ at night. Relative humidity is high all year round, and varies between $50 \%$ and $75 \%$. This climatic condition supports a rich tropical rain forest vegetation that has been interfered with in places by human activities and replaced by secondary vegetation such as grasses and shrubs, and scattered cultivation of rubber and palm trees.

Geological Setting: Three dichronous stratigraphic units from Eocene to Recent have been identified (Asseez, 1979, Short and Stauble, 1967). The sedimentary sequences were laid down under marine, transitional and continental environments. The Akata Formation makes up the basal units composed mainly of marine shales. This is followed in the depositional sequence by the paralic Agbada Formation. The Benin Formation makes up the uppermost units consisting of fluviatile gravels and sand deposits. 
The area of study is situated in the transitional zone between the Sombreiro - Warri deltaic swamp and the Benin Formation. It is generally made up of superficial deposits of Quaternary age. The sediments are mainly lateritized sands and gravels which gives it a characteristic brown-reddish brown coloration.

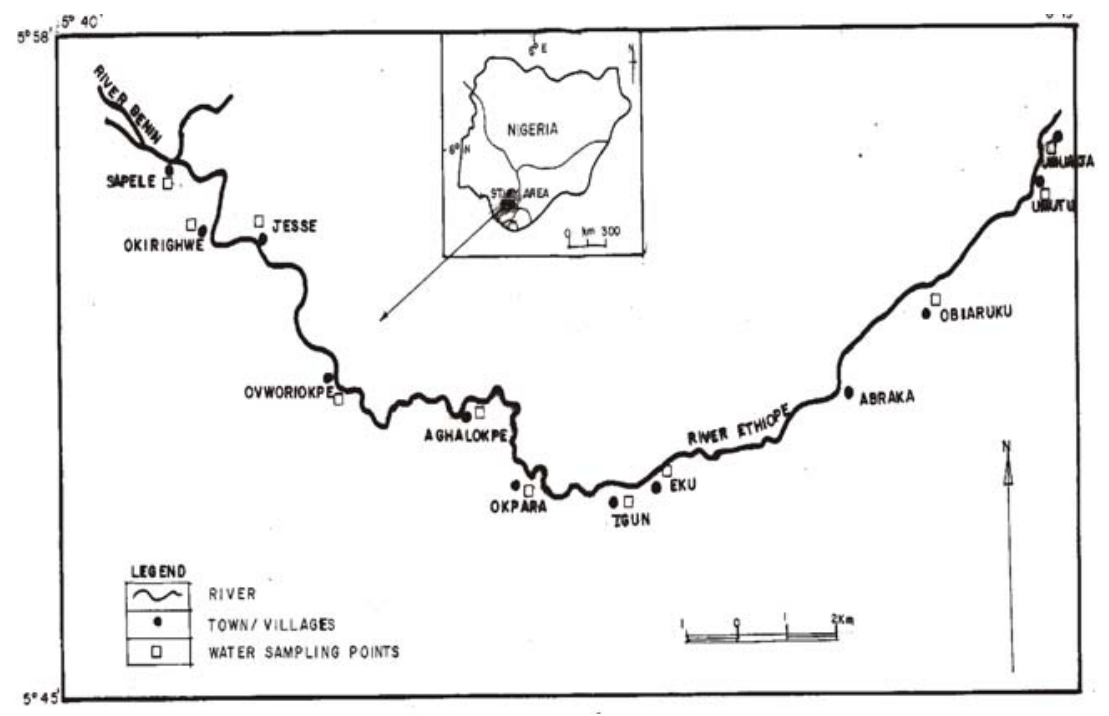

Fig 1: Map of River Ethiope showing water sampling points (inset: Map of Nigeria showing the study area)

\section{MATERIALS AND METHODS}

Hydrological measurements were carried out involving depth, width and flow velocity at several locations along the Ethiope river course, to estimate the river discharge. Baseline flow was subtracted from total discharge to obtain direct run-off. Lithological logs within the study area were constructed from borehole cuttings obtained from tube wells, along the course of the Ethiope River. These cuttings were also subjected to sedimentological analysis from which hydraulic conductivities were estimated using the Hazen formula (Freeze and Cherry, 1976). From the aquifer thickness and results of hydraulic conductivities, the aquifer transmissivity values were computed. For the determination of the aquifer vulnerability potential, the DRASTIC model (Aller et al, 1987) was used. For this, fresh holes were drilled to determine depth to water table, and estimate net-recharge. Soil type and variation were also deduced from these holes and from existing boreholes cuttings. The topography, including ground surface elevation and slope variations was deduced from existing topographic maps and field GPS measurements. These parameters were rated and weighted according to the procedures of Deichert (1992); Vrba and Zaporozec (1994). The ratings were multiplied by their respective weights, and these products are summed to obtain the final score or DRASTIC index.

For physico-chemical and microbial analysis, 1litre replicate water samples were collected into clean and sterilized plastic cans respectively. Unstable physical parameters such as $\mathrm{pH}, \mathrm{DO}$ and temperature were measured in-situ respectively using the digital $\mathrm{pH}$ and DO meters, and Celsius thermometer. The samples were kept in ice bags and transported to the laboratory. Analytical procedures for both physicochemical and bacteriological parameters were in accordance with the specifications of APHA (1992). The concentration of $\mathrm{Na}^{+}$and $\mathrm{K}^{+}$were determined with a flame emission analyzer. $\mathrm{Ca}^{2+}$ and $\mathrm{Mg}^{2+}$ were measured by EDTA titrimetry, while $\mathrm{Cl}^{-}, \mathrm{HCO}^{-}$and $\mathrm{CO}^{2}$ were also determined by various titrimetric methods. $\mathrm{NO}^{2}$ was measured by colorimetry. The concentrations of heavy metals were determined using the Atomic Absorption Spectrophotometer. In the determination of total coliform bacteria and E. Coli, the multiple tube fermentation technique was used.

\section{RESULTS AND DISCUSSION}

Hydrology: The River Ethiope and its tributaries constitute the major river draining the area. It flows southwestwards to Igun, where it changes direction to the northwest into River Benin at Sapele, then finally emptying into the Atlantic Ocean. The monthly discharge rate of the river for the years 2001 and 2002 are presented in Figure 2. This figure indicates that lowest discharge rate of the river is recorded in June, which increases steadily reaching its peak in October. The river discharge is related to the pattern of rainfall distribution in the area, with a time lag of about three months. No flood events have been recorded in the upper and middle courses of the river. This is as a 
result of the wide, gently sloping floodplain, unconsolidated nature, high porosity and permeability of the sediments, which allow for rapid infiltration and downward movement of water. Discharge measurements from two storm events of $66 \mathrm{~mm}$ and $39 \mathrm{~mm}$ produced a direct run-off of $15.5 \mathrm{~m}^{3} / \mathrm{s}$ and $13.0 \mathrm{~m}^{3} / \mathrm{s}$ respectively in the river (Table 1) accounting for less than 3\% of the total run-off of the River Ethiope. This implies that precipitation produces substantial infiltration rather than run-off. Other studies have also indicated that the surface runoff is usually poor in humid vegetated basins (Freeze and Cherry, 1979).

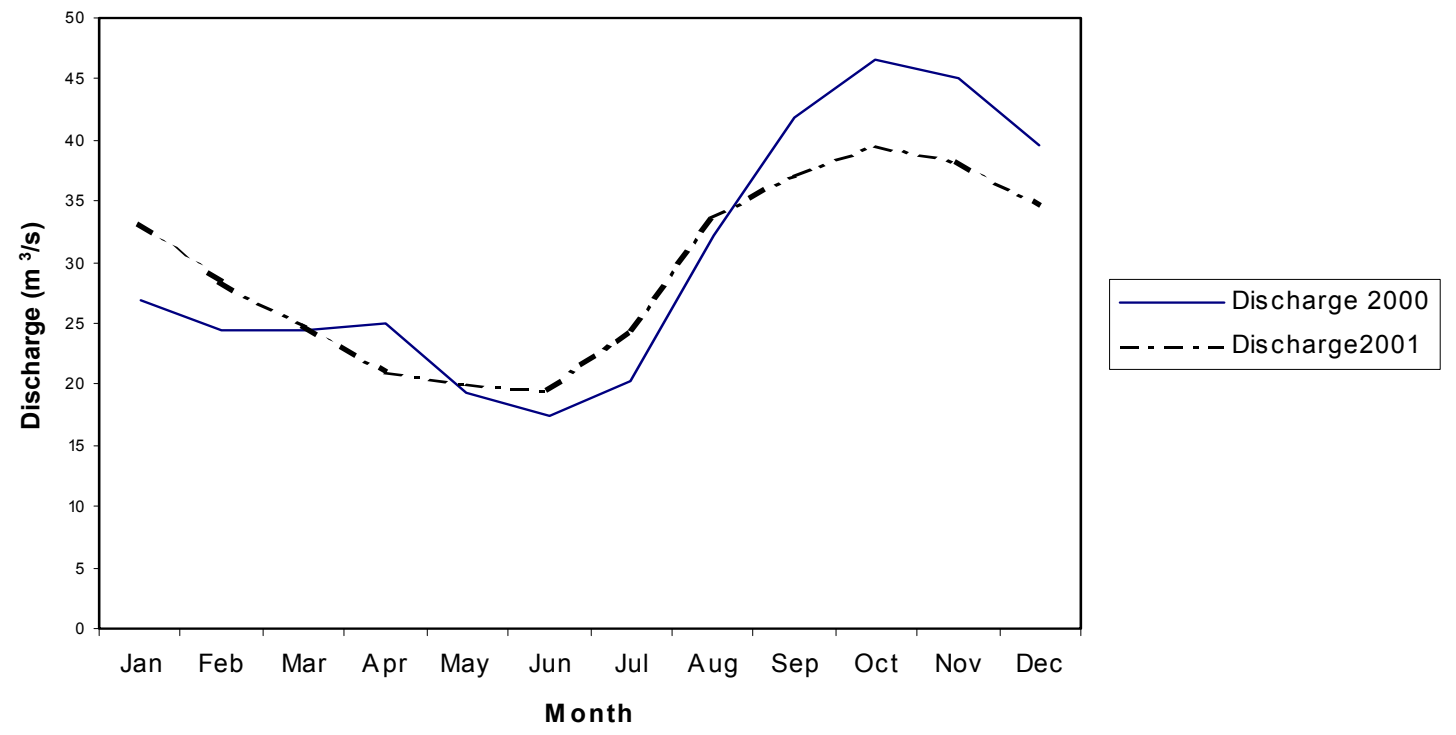

Fig 2. Discharge of River Ethiope for the years 2001 and 2002

The subsurface lithostratigrapy of the Ethiope watershed is presented in Figure 3. This consists of a covering of lateritic soil underlain by thin horizons of sandy silt or clayey sand. Below these is a predominantly unconsolidated sandy aquifer with clay and silt intercalations, which typifies the Benin
Formation. The aquifer unit is generally deeper than 20 metres and consists of moderately sorted medium to coarse sands with transmissivity value exceeding $600 \mathrm{~m}^{2} /$ day. This aquifer is semi-confined to unconfined and groundwater is therefore in hydrostatic equilibrum with the atmosphere.

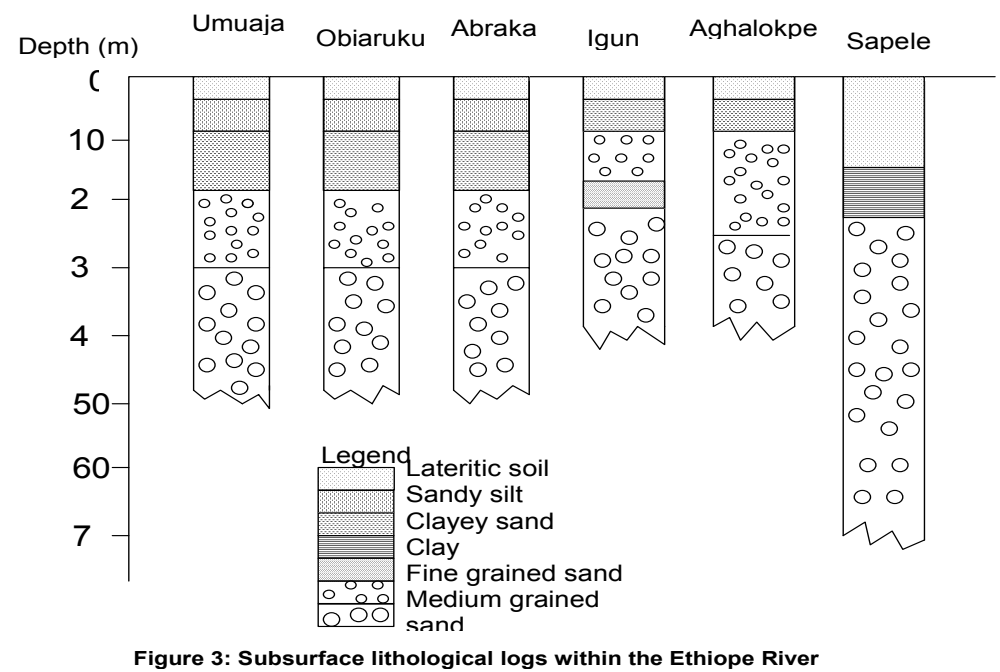

Surface Water Quality: Tables 3 and 4 show the statistical summary of both physico-chemical and bacteriological compositions of water samples from River Ethiope. The variation in composition is represented graphically in Figures 4 and 5 respectively. $\mathrm{pH}$ occurs in the mildly acidic range of 5.44 to 5.86 but generally becomes more alkaline downstream. Turbidity values recorded for the water samples range between 3.98 to $8.12 \mathrm{NTU}$, and are predominantly higher than the recommended limits 
for drinking water (WHO, 1996). Total dissolved solids (TDS) and electrical conductivity Ec) have values in the range of 45.80 to $62.00 \mathrm{mg} / \mathrm{l}$ and 94.00 to $127.00 \mu \mathrm{s} / \mathrm{cm}$ respectively. These two parameters are generally more enhanced upstream and decreases steadily downstream, which suggest the removal of dissolved solids from water by precipitation in response to increasing alkalinity downstream. The stream flows over sediments with dominant silicate mineralogies. Chemically, these minerals act as bases and as water-rock interaction progresses, there is a gradual increase in $\mathrm{pH}$ (Bjorn et al, 2001). Total hardness $\left(\mathrm{H}_{\mathrm{T}}\right)$ has concentration values of 25.50 to $35.00 \mathrm{mg} / \mathrm{l}$ which according to the water hardness parameters of Sawyer and McCarty (1976), indicate soft water of good laundry and some industrial use.

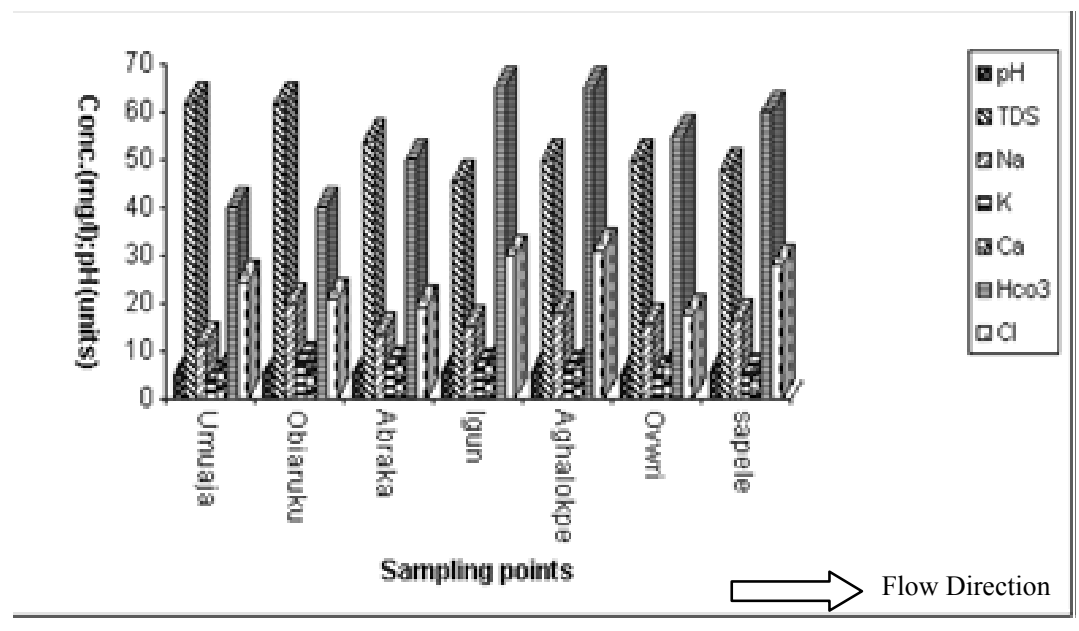

Fig 4: Physico-chemical Composition of River Ethiope water sample

The cations $\mathrm{Na}^{+}, \mathrm{K}^{+}, \mathrm{Ca}^{2+}, \mathrm{Mg}^{2+}$ show maximum concentration of $19.85 \mathrm{mg} / 1,7.30 \mathrm{mg} / 1,7.21 \mathrm{mg} / \mathrm{l}$ and $5.84 \mathrm{mg} / \mathrm{l}$ respectively. The contents of trace metals $\mathrm{Fe}(0.14-0.21 \mathrm{mg} / \mathrm{l}), \mathrm{Pb}(0.06-0.05 \mathrm{mg} / \mathrm{l}), \mathrm{Cr}(0.02-$ $0.05 \mathrm{mg} / \mathrm{l}), \mathrm{Cu}(0.06-0.12 \mathrm{mg} / \mathrm{l})$ and $\mathrm{Mn}(0.01-0.05$ $\mathrm{mg} / \mathrm{l})$ generally occur within the mandatory limits for domestic water (WHO, 1996). On the other hand, Cd (0.01-0.05 $\mathrm{mg} / \mathrm{l})$ shows enhanced values predominantly in excess of the recommended limits. Sodium adsorption ratio lies in the range 0.9 to 2.5 and suggests that surface water will be of excellent irrigation quality. The concentration of $\mathrm{HCO}_{3}{ }^{-} \mathrm{Cl}^{-}$, $\mathrm{SO}_{4}{ }^{2-}, \mathrm{NO}_{3}{ }^{2-}$ and $\mathrm{PO}_{4}{ }^{2-}$ range respectively from 40.00 to $70.00 \mathrm{mg} / \mathrm{l}, 17.55$ to $29.84 \mathrm{mg} / \mathrm{l}, 0.25$ to $0.58 \mathrm{mg} / \mathrm{l}$, 0.25 to $0.41 \mathrm{mg} / \mathrm{l}$ and 0.20 to $0.33 \mathrm{mg} / \mathrm{l}$. With the exception of chloride that has elevated concentration values (although within the WHO limit), which probably reflects the effect of tidewater incursion from the sea, the composition of the river water is generally similar to that of mean world water (Hem, 1984).

Table 1. Runoff Estimation Along the River Ethiope

\begin{tabular}{llllll}
\hline Rainfall $(\mathrm{mm})$ & $\begin{array}{l}\text { Total Discharge } \\
\left(\mathrm{m}^{3} / \mathrm{s}\right)\end{array}$ & $\begin{array}{l}\text { Base } \\
\left(\mathrm{m}^{3} / \mathrm{s}\right)\end{array}$ & flow & $\begin{array}{l}\text { Direct } \\
\left(\mathrm{m}^{3} / \mathrm{s}\right)\end{array}$ & runoff \\
66 & 557.0 & 540.6 & & 15.5 & \\
39 & 511.8 & 451.8 & & 13.0 & \\
\hline
\end{tabular}

Table 2. Result of Groundwater Vulnerability Assessment Based on the DRASTIC Model

\begin{tabular}{lllll}
\hline Factor & Parameters & Rating (R) & Weight (W) & R x W \\
Depth to water table (D) & $30.35 \mathrm{~mm}$ & 3.5 & 5 & 17.5 \\
Net Recharge (R) & $>900 \mathrm{~mm}$ & 10 & 3 & 30 \\
Aquifer media (A) & Sand & 8 & 3 & 24 \\
Soil media (S) & Sandy silt & 8 & 2 & 16 \\
Topography (T) & $0-2 \%$ & 10 & 1 & 10 \\
Impact of vadose zone (I) & Sand & 8 & 5 & 40 \\
Hydraulic conductivity (C) & E-03m/s & 8 & 4 & 32 \\
\hline \multicolumn{5}{c}{ DRASTIC index } \\
\hline
\end{tabular}


The bacteriological parameters determined for the water samples taken along the course of the river (Table 4 and Figure 5) reveal the vulnerability of the river to contamination by pathogens. Parameters including total coliforms and Escherichia coli have mean values of $502.71 \mathrm{MPN} / 100 \mathrm{ml}$ and 145.57 MPN/100ml respectively that greatly exceed the WHO (1996) tolerance levels of 0 counts of total coliform $/ 100 \mathrm{ml}$ in $95 \%$ of water samples tested throughout any a 12 month period, and 0 counts of $E$. coli per every $100 \mathrm{ml}$. This shows that endemic morbidity exists in these waters with high potential health risks. The likely effects are water borne diseases. The trend in the distribution of the microbial population indicates a steady and significant increase from the river source (Umuaja) to Aghalokpe and a sharp decline from Ovwri to Sapele. This trend mirrors the intensity of human activities in the different sections of the river course. Consequently, microbial disinfection procedures may be needed to upgrade the river water quality for potability

Table 3: Statistical Summary of Physico-Chemical Qualities of Surface and Groundwater Within Ethiope Watershed.

\begin{tabular}{|c|c|c|c|c|c|}
\hline \multicolumn{6}{|l|}{ Variables $\mathrm{n}=7$} \\
\hline & \multicolumn{2}{|c|}{ Surface Water } & \multicolumn{3}{|l|}{ Groundwater } \\
\hline & Range & Mean \pm std. & $\overline{\text { Range }}$ & $\begin{array}{l}\text { Mean } \pm \text { std. } \\
\text { guidelines }\end{array}$ & WHO 1996 \\
\hline $\mathrm{PH}$ & $5.28-5.86$ & $5.62 \pm 0.22$ & $6.42-7.06$ & $6.63 \pm 0.26$ & $6.5-8.5$ \\
\hline Turbidity(NTU) & $3.48-8.12$ & $5.81 \pm 1.54$ & $1.16-3.20$ & $2.52 \pm 0.68$ & \\
\hline $\mathrm{TDS} \mathrm{mg} / 1$ & $45.80-62.00$ & $53.13 \pm 6.56$ & $35.00-45.50$ & $42.24 \pm 3.57$ & 1000 \\
\hline $\mathrm{EC}$ us/cm & $94.00-127.00$ & $107.43 \pm 13.50$ & $65.00-98.00$ & $85.71 \pm 10.59$ & \\
\hline DO mg/l & $4.40-7.20$ & $6.06 \pm 0.45$ & $5.20-7.60$ & $6.400 \pm 0.95$ & 5 \\
\hline $\mathrm{Na} \mathrm{mg} / \mathrm{l}$ & $3.91-7.30$ & $15.83 \pm 2.72$ & $14.60-27.05$ & $19.86 \pm 4.27$ & 200 \\
\hline $\mathrm{K}$ mg/l & $3.91-7.30$ & $5.65 \pm 1.15$ & $5.20-8.73$ & $7.09 \pm 1.46$ & 12 \\
\hline $\mathrm{Ca} \mathrm{mg/1}$ & $4.01-7.21$ & $6.02 \pm 1.25$ & $3.21-9.62$ & $5.49 \pm 2.24$ & 200 \\
\hline $\mathrm{Mg} \mathrm{mg/1}$ & $1.46-5.84$ & $3.75 \pm 1.40$ & $2.43-4.86$ & $3.12 \pm 0.84$ & 50 \\
\hline $\mathrm{Fe} \mathrm{mg} / 1$ & $0.14-0.21$ & $0.17 \pm 0.02$ & $0.11-0.18$ & $0.14 \pm 0.03$ & 0.3 \\
\hline $\mathrm{Zn} \mathrm{mg/1}$ & $0.65-1.31$ & $0.98 \pm 0.27$ & $0.65-1.31$ & $0.88 \pm 0.25$ & 3 \\
\hline $\mathrm{Pb} \mathrm{mg} / 1$ & $0.06-0.11$ & $0.08 \pm 0.02$ & $0.03-0.11$ & $0.06 \pm 0.02$ & 0.01 \\
\hline $\mathrm{Cu} \mathrm{mg/1}$ & $0.06-0.12$ & $0.09 \pm 0.02$ & $0.05-0.09$ & $0.07 \pm 0.02$ & 2 \\
\hline $\mathrm{Cr}$ mg/1 & $0.02-0.05$ & $0.04 \pm 0.01$ & $0.01-0.04$ & $0.02 \pm 0.01$ & 0.05 \\
\hline $\mathrm{Cd} \mathrm{mg/l}$ & $0.01-0.05$ & $0.03 \pm 0.01$ & $0.01-0.02$ & $0.01 \pm 0.004$ & 0.003 \\
\hline $\mathrm{HCO}_{3} \mathrm{mg} / \mathrm{l}$ & $40.00-65.00$ & $53.57 \pm 10.69$ & $31.50-80.00$ & $58.21 \pm 21.37$ & \\
\hline $\mathrm{Cl} \mathrm{mg/l}$ & $17.55-31.15$ & $24.50 \pm 5.36$ & $24.57-35.10$ & $29.32 \pm 3.79$ & 250 \\
\hline $\mathrm{SO}_{4} \mathrm{mg} / 1$ & $0.25-0.58$ & $0.42 \pm 0.11$ & $0.27-0.52$ & $0.37 \pm 0.08$ & 250 \\
\hline $\mathrm{NO}_{3} \mathrm{mg} / \mathrm{l}$ & $0.26-0.41$ & $0.34 \pm 0.05$ & $0.19-0.55$ & $0.38 \pm 0.16$ & 50 \\
\hline $\mathrm{PO}_{4} \mathrm{mg} / 1$ & $0.20-0.33$ & $0.28 \pm 0.04$ & $0.23-19.00$ & $2.93 \pm 7.08$ & \\
\hline $\mathrm{TH} \mathrm{mg} / 1$ & $25.50-35.00$ & $30.93 \pm 3.17$ & $29.00-45.00$ & $35.79 \pm 6.20$ & 500 \\
\hline SAR & $1.30-2.20$ & $1.44 \pm 0.56$ & $0.90-2.50$ & $1.73 \pm 0.50$ & \\
\hline
\end{tabular}

Groundwater Quality: A statistical summary of the physico-chemical and bacteriological composition of groundwater samples along the course of the Ethiope River is shown in Table 3 and 4 . The variation of the values along the course of the river is represented in Figures 6 and 7 respectively. $\mathrm{pH}$ values lie in the range 6.24 to 7.06 . The values of turbidity vary from 1.16 to $3.20 \mathrm{NTU}$, indicating clear water of low turbidity. TDS, $\mathrm{EC}$ and $\mathrm{H}_{\mathrm{T}}$ vary from 35.00 to 45.50 $\mathrm{mg} / \mathrm{l}, 65.00$ to $98.00 \mu \mathrm{s} / \mathrm{cm}$ and 29.00 to $45.00 \mathrm{mg} / 1$ respectively indicating soft freshwater of low salinity.

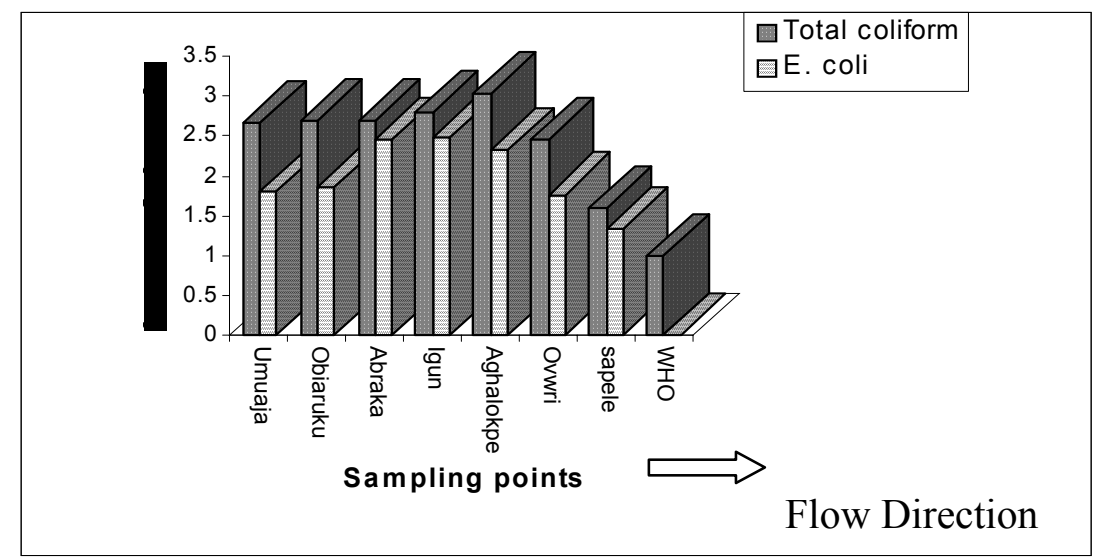

OMO-IRABOR, O O; OLOBANIYI, S $\mathrm{B}$ Fition of River Ethiope water samples 
The ranges of the cation compositions in $\mathrm{mg} / \mathrm{l}$ are as follows: $\mathrm{Ca}^{2+}$ (3.21-9.62), $\mathrm{Mg}^{2+}(2.43-4.86), \mathrm{Na}^{+}$ (14.60-27.05) and $\mathrm{K}^{+}(5.20-8.73)$. Others include $\mathrm{Fe}$ (0.11-0.18), $\mathrm{Pb}(0.03-0.11), \mathrm{Cr}(0.01-0.04), \mathrm{Cu}(0.05-$ $0.09), \mathrm{Mn}(0.02-0.04), \mathrm{Zn}(0.65-1.31)$ and $\mathrm{Cd}(0.01-$ 0.02 ). Anions have compositional ranges in $\mathrm{mg} / \mathrm{l}$ of $\mathrm{HCO}_{3}{ }^{-}(31.50-80.00), \mathrm{Cl}^{-}(24.57-35.10), \mathrm{SO}_{4}{ }^{2-}(0.27-$ $0.52)$ and $\mathrm{PO}_{4}^{2-}(0.19-0.29)$. These ions generally occur within the specified limits for domestic usage (WHO, 1996). Also, the low SAR values $(1.2-2.5)$ indicate good irrigation quality. Nevertheless, the elevated chloride values recorded in groundwater, which is similar to that for surface water, suggests some groundwater recharge from the tide-influenced River Ethiope.

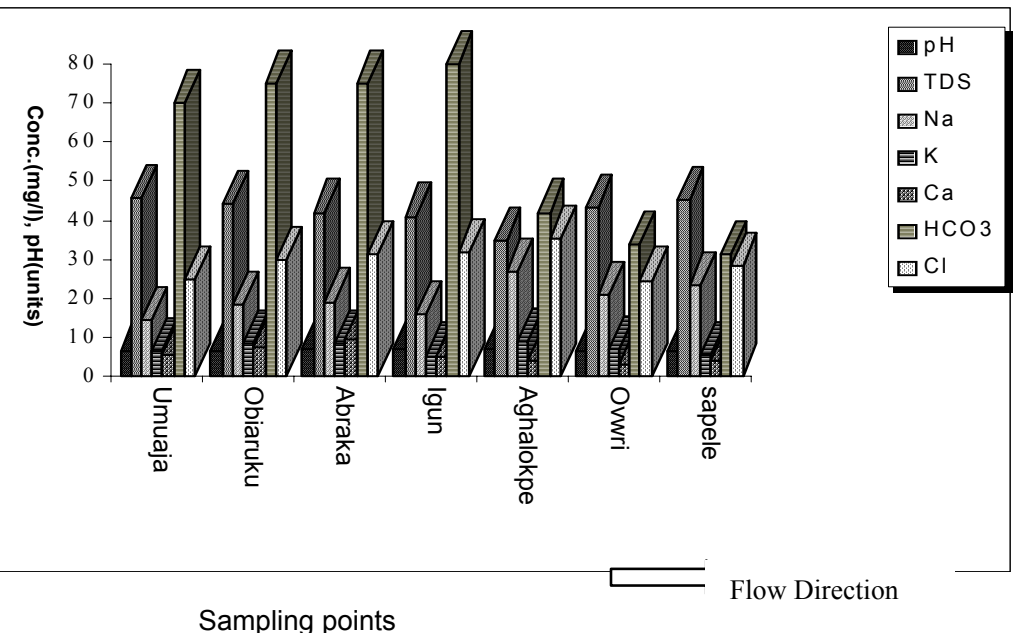

Fig 6. Physico-chemical composition of groundwater within the Ethiope River watershed

The microbial content of ground water samples is generally high (Table 4 and Figure 7). The mean composition of the parameters determined is total coliforms $614.42 \mathrm{MPN} / 100 \mathrm{ml}$ and E. coli 112.85 MPN/100ml. This indicates a significant microbial contamination of groundwater, similar to what obtains in surface water and will require same remediation as in surface water to improve its quality for potability.

Groundwater-Surface water Interaction: The unconfined nature of the underlying aquifer permits a continuous interaction between ground and surface water within the study area. The impairment of either ground or surface water quality may therefore be reflected in the other. To assess groundwater-surface water interaction, the equality of mean (t-test) and Variance (F-test) for selected chemical constituents $\left(\mathrm{Cl}^{-}, \mathrm{NO}_{3}{ }^{2-}, \mathrm{SO}_{4}{ }^{2-}, \mathrm{PO}_{4}^{2-}, \mathrm{Na}^{+}, \mathrm{Ca}^{2+}, \mathrm{Mg}^{2+}\right)$ from the two populations were used. The level of significance for both tests was fixed at 5\% (two-tailed $=2.5 \%$ for $\mathrm{t}$ test).

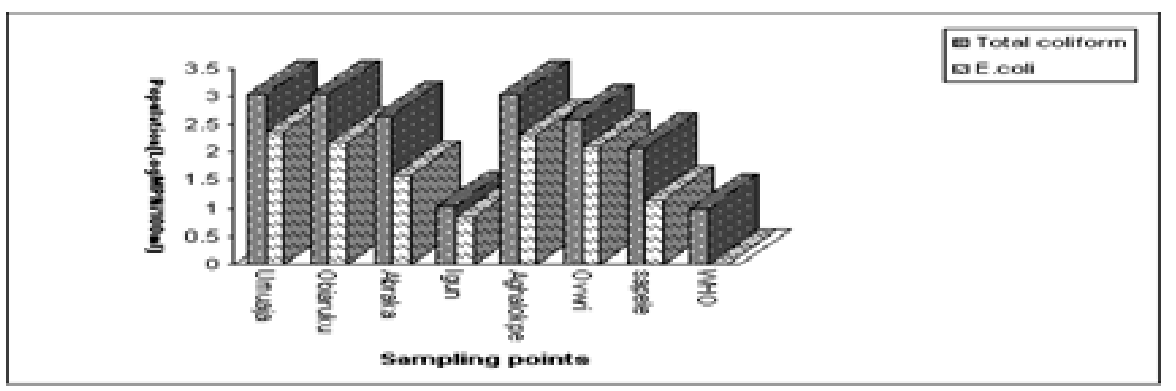

Fig 7 Microbial composition of groundwater within the Ethiope River watershed 
The results obtained from the statistical analyses are presented in Table 5. $\mathrm{Cl}^{-}, \mathrm{SO}_{4}{ }^{2-}, \mathrm{PO}_{4}{ }^{2-}, \mathrm{Na}^{+}, \mathrm{Ca}^{2+}$, $\mathrm{Mg}^{2+}$ showed non-significance in variation of mean and variance between the two populations. This apparent homogeneity in ionic concentration coupled with similarly high microbial load within the two environments, suggests considerable groundwater- surface water interaction and inter-mixing. Nevertheless, $\mathrm{NO}_{3}{ }^{2-}$ indicates significant variation in $\mathrm{t}$ and $\mathrm{F}$ values for the two water sources. This suggests the nearness of groundwater sampling points to septic tanks and/or the activity of denitrifying bacteria in the surface water.

Table 4: Statistical Summary of Microbial Composition of Surface and Groundwater Within Ethiope Watershed.

\begin{tabular}{lllllll}
\hline Variables* $\mathrm{n}=7$ & \multicolumn{2}{c}{ Surface water } & & \multicolumn{2}{c}{ Groundwater } & \multicolumn{2}{c}{ WHO 1996} \\
\cline { 2 - 3 } Total coliform & Range & Mean \pm std. & & Range & Mean \pm std & \\
E. Coli & $39.00-1100$ & $502.71 \pm 326$ & & $11.00-1100$ & $614.42 \pm 479$ & $0.05 / 100 \mathrm{ml}$ \\
& $21.00-305$ & $145.57 \pm 119.60$ & & $7.00-240$ & $112.85 \pm 94.61$ & $0 / 100 \mathrm{ml}$
\end{tabular}

$* \overline{\mathrm{MPN}} / 100 \mathrm{ml}$

Table 5: Result of $\mathrm{t}$ and $\mathrm{F}$ statistics of surface and groundwater of the River Ethiope watershed

\begin{tabular}{lll}
\hline Parameter & $\mathrm{t}-$ test & $\mathrm{F}-$ test \\
\hline Bicarbonate & 0.04 & 3.96 \\
Chloride & 2.11 & 0.58 \\
Nitrate & 6.66 & 9.00 \\
Sulphate & -0.08 & 0.76 \\
Phosphate & -0.27 & 0.56 \\
Sodium & 0.61 & 2.87 \\
Potassium & 0.92 & 1.64 \\
Calcium & -0.30 & 3.79 \\
\hline Magnesium & -0.98 & 0.42 \\
\hline
\end{tabular}

Aquifer Vulnerability Assessment: In order to investigate the reason for such groundwater - surface water interaction, the vulnerability to contamination of groundwater was assessed. This assessment was based on the evaluation of several natural factors and their capacity for enhancing or attenuating the percolation of contaminants to the water table. The parameters involved and their weighted results are indicated in Table 2 . The result obtained from this model (DRASTIC index $=169.50$ ) predicts moderately high vulnerability of the aquifer to contamination by percolating pollutants, and explains the reason for the significant groundwatersurface water interaction in the area. This vulnerability to contamination by the aquifer can be related to such factors as the shallow and unconfined to semi-confined nature of the aquifer, and the moderate to high permeability of the overlying sediments that allow for rapid water infiltration.

\section{REFERENCES}

Adiotomre EA; Adaikpoh EO; Erhisere O (1999). The gravel packing properties of Sand Deposit in the Ethiope River Catchment. GeoResearch 4: 21-26.

Aller L; Bennet T; Lehr JH; Petty RJ (1987). DRASTIC: a standardized system for evaluating groundwater pollution potential using hydrogeologic settings, U.S. EPA Report $600 / 2-85 / 018$

APHA (1992). Standard methods for the examination of water and wastewater. $16^{\text {th }}$ edition, American Public Health Association, Washington, D. C.
Asseez, LO (1979). Review of the stratigraphy, sedimentation and structure of the Niger Delta. In Geology of Nigeria by Kogbe, CA (Ed). Elizabethan Press, Lagos. Pp 311-324.

Bjorn, F; David, B; Ulrich, S (2001). The chemistry of Norwegian groundwaters: IV. The pH-dependence of element concentrations in crystalline bedrock groundwaters. The Sci. Of the Total Environment 277: 101-117

Deichert, A (1992). Groundwater quality model for evaluating the pollution of large areas. Texas Water Resources 16(1): 56-67

Freeze, RA; Cherry, JA (1976). Groundwater. Prentice-Hall, Englewood Cliffs, New Jersey.

Hem, JD (1984). Study and interpretation of chemical characteristics of natural water. USGS Water Supply Paper no. $1473,264 p$

Ikomi, RB (1992). Some aspects of the biology of the dwarf cichlid Pelvicachromis pulcher (Boulenger 1901) in River Ethiope, Nigreria. Abraka Jour. Agric. 1: 125-1454.

Ikomi, RB (1996). The biology of the African leaf fish Polycentropsis abbreviata (Boulenger 1905) in the River Ethiope, Nigeria. Acta Icthyologica et. PISC (XXVI), 1-14

Sawyer CN; McCarthy PL (1967). Chemistry for sanitary engineers. $2^{\text {nd }}$ ed. McGraw-Hill, New York. 518p.

Short, KC; Stauble, AJ (1967). Outline of geology of Niger Delta. American Assoc. Petroleum Geologists Bull. 51: 761-779.

Vrba, JA; Zaporozec, A (1994). Guideline on mapping groundwater and vulnerability. Jour. Inter. Ass. Hydrogeologists 16, 39-48

World Health Organization (1996). Guidelines for drinking water quality. $2^{\text {nd }}$ ed.: Health criteria and other supporting information. Geneva. 
